\title{
The optimal number of heifer calves to be reared as dairy replacements
}

\author{
N. Mohd Nor, ${ }^{*} \dagger^{1}$ W. Steeneveld, $\ddagger$ M. C. M. Mourits, $\ddagger$ and H. Hogeveen ${ }^{*} \ddagger$ \\ *Department of Farm Animal Health, Faculty of Veterinary Medicine, Utrecht University, PO Box 80151, 3508 TD, the Netherlands \\ †Department of Preclinical Sciences, Faculty of Veterinary Medicine, Universiti Putra Malaysia, 43400 Serdang, Selangor, Malaysia \\ ¥Business Economics Group, Wageningen University, PO Box 8130, 6706 KN, Wageningen, the Netherlands
}

\begin{abstract}
Dairy farmers often keep almost all their newborn heifer calves despite the high cost of rearing. By rearing all heifer calves, farmers have more security and retain flexibility to cope with the uncertainty in the availability of replacement heifers in time. This uncertainty is due to mortality or infertility during the rearing period and the variation in culling rate of lactating cows. The objective of this study is to provide insight in the economically optimal number of heifer calves to be reared as replacements. A herd-level stochastic simulation model was developed specific for this purpose with a herd of 100 dairy cows; the biological part of the model consisted of a dairy herd unit and rearing unit for replacement heifers. The dairy herd unit included variation in the number of culled dairy cows. The rearing unit incorporated variation in the number of heifers present in the herd by including uncertainty in mortality and variation in fertility. The dairy herd unit and rearing unit were linked by the number of replacement heifers and culled dairy cows. When not enough replacement heifers were available to replace culled dairy cows, the herd size was temporarily reduced, resulting in an additional cost for the empty slots. When the herd size reached 100 dairy cows, the available replacement heifers that were not needed were sold. It was assumed that no purchase of cows and calves occurred. The optimal percentage of 2-wk-old heifer calves to be retained was defined as the percentage of heifer calves that minimized the average net costs of rearing replacement heifers. In the default scenario, the optimal retention was $73 \%$ and the total net cost of rearing was estimated at $€ 40,939$ per herd per year. This total net cost was $6.5 \%$ lower than when all heifer calves were kept. An earlier first-calving age resulted in an optimal retention of $75 \%$, and the net costs of rearing were $€ 581$ per herd per year lower than in the default scenario. For herds with a lower or higher culling rate of dairy cows (10 or $40 \%$ instead of $25 \%$ in the default
\end{abstract}

Received May 6, 2014.

Accepted October 31, 2014.

${ }^{1}$ Corresponding author: N.B.MohdNor@uu.nl scenario), it was optimal to retain 35 or $100 \%$ of the heifer calves per year. Herds that had a lower or higher cost of empty slots ( $€ 50$ or $€ 120$ per month instead of $€ 82$ in the default scenario) had an optimal retention of 49 or $83 \%$ per year; the optimal retention percentage was dependent on farm and herd characteristics. For Dutch dairy farming conditions, it was not optimal to keep all heifer calves.

Key words: dairy replacement, young stock rearing, culling, cost

\section{INTRODUCTION}

Most Dutch dairy farmers, and many farmers in other major milk-producing countries, rear their own young stock to provide replacement heifers. Heifer rearing is expensive, with high costs for feed, labor, and housing (Gabler et al., 2000; Tozer and Heinrichs, 2001). Recent estimates of the cost of rearing a replacement heifer in the Netherlands range between $€ 1,400$ and $€ 1,700$ per heifer (Mohd Nor et al., 2012).

Farmers are aware that heifer rearing is expensive, but they still keep (almost) all their newborn heifer calves to ensure enough young stock are available to replace culled dairy cows. When too much young stock is kept, they are sold to other farms or sold for export. The uncertainty in the availability of full-grown heifers occurs due to mortality and growth and reproduction problems in the rearing period. The risk of mortality of calves after birth was reported to vary between 1 and 8\% (Svensson et al., 2006; Mee, 2008; Raboisson et al., 2013). Growth and reproduction problems (e.g., infertility) reduce the number of heifer calves reaching their first calving because these heifers have either a higher probability to be culled during rearing (Hultgren et al., 2008; Brickell et al., 2009; Brickell and Wathes, 2011) or a high first-calving age (and therefore delayed availability for replacement). Mohd Nor et al. (2014) reported that the average culling rate of lactating cows in Dutch dairy herds was 25\%, ranging between 23 and $28 \%$ in different years. For individual herds, the variation between years was even higher. There are several reasons why the culling rate varies between years. One potential reason is an outbreak of an endemic disease, 
such as bovine viral diarrhea or infectious bovine rhinotracheitis (Vonk Noordegraaf et al., 1998).

Various studies have evaluated the costs of heifer rearing (Gabler et al., 2000; Mohd Nor et al., 2012), the mortality of heifer calves (Svensson et al., 2006; Raboisson et al., 2013), and the culling of dairy cows (Pinedo et al., 2010; Mohd Nor et al., 2014). All this information is needed to determine the optimal number of heifer calves to be reared as replacements for culled dairy cows. No study, however, has incorporated the uncertainty of losing heifer calves and variation in the culling rate of dairy cows to determine the optimal number of replacement heifer calves. In addition, the economic consequences of keeping too few or too many heifer calves have not yet been investigated.

The objective of the current study was to provide insight on the economically optimal number of heifer calves to be reared as replacement heifers to support tactical management decisions. We developed a stochastic model that determined the optimal number of heifer calves to be reared by minimizing the net cost of rearing replacement heifers. The model included uncertainty in the mortality and fertility of heifer calves and the culling rate of dairy cows.

\section{MATERIALS AND METHODS}

\section{Model Development}

To determine the optimal number of heifer calves that should be retained to replace culled dairy cows, a herd-level Monte Carlo simulation model was developed in Microsoft Excel (Microsoft Corporation, Redmond, WA,) using @Risk add-on software (Palisade Corporation, Ithaca, NY). The settings of the model were chosen to represent a Dutch dairy herd that rears its own replacement heifers.

The model simulated both the dairy herd unit and the young stock rearing unit of the herd. A closed herd (i.e., no purchase of cows and calves) was assumed. Moreover, a management approach ensuring good herd health was assumed. The model was simulated with monthly time steps (stages), and included 83 monthly stages. As the transportation of newborn calves before the age of 2 wk is prohibited in the Netherlands, an additional stage was defined to capture these first 2 wk, resulting in a total of 84 stages. Each replication covered in total a period of $7 \mathrm{yr}$, and started with a herd of 100 dairy cows and no heifer calves present. At every stage, there are several young stock with an age varying between 2 wk to first calving age. When the decision was made to retain all heifer calves, after the third year, the model reached the steady state. Thus, the average result for yr $3,4,5,6$, and 7 was simi- lar. When the decision was made to keep fewer heifer calves, the model showed that it reached a steady state at yr 7 . The economic analysis was therefore based on the simulated results of yr 7 . This has also allowed the simulated system to achieve a stable herd structure in accordance with the simulated scenarios (described in the next section).

In the dairy herd unit of the simulation model, the number of calvings and subsequent number of newborn heifer calves was simulated for each stage by using binomial distribution, based on the herd size, calving interval, and the male-to-female ratio. The number of culled dairy cows was also simulated for each stage by using the binomial distribution.

In the rearing unit, the following states were defined: dead, inseminated, pregnant, infertile, and first-calving age. At each stage, the number of heifers in each state was simulated by using binomial distribution. A replacement heifer was defined as a reared heifer that had reached first-calving age.

At each stage, the heifer-rearing unit and the dairy herd unit were linked by comparing the number of available replacement heifers in the heifer rearing unit with the number of culled dairy cows in the dairy herd unit. Available replacement heifers filled up the slots that were left empty when dairy cows were culled. If no replacement heifer was available to replace a culled dairy cow, the herd size was temporarily reduced, which resulted in an empty slot for at least 1 mo. If more replacement heifers were available than required (i.e., the herd size had reached 100 dairy cows), the redundant replacement heifer was sold as an excess heifer.

The model contained a large number of possible combinations of states at each stage. Therefore, 10,000 replications were carried out to provide stable results and insight into the possible range of outcomes. Inputs were based on relevant scientific literature where available, followed by information from organizations and experts active in the Dutch dairy industry. If no information was available, the authors' expertise was used.

Biological Input. The number of calves born was specified as a binomial distribution, with the herd size and calving interval as input. The probability of a female calf was assumed to be $50 \%$. The number of culled dairy cows was specified as a binomial distribution with an average culling rate of dairy cows of $25 \%$ as input (Table 1).

Within the rearing unit, the number of calves that died per stage was also specified as a binomial distribution, using the number of calves in that stage and a stage-specific probability of death (Table 1) as inputs. The BW of heifers during the rearing period was based on Koenen and Groen, (1996; Table 1). The process of insemination was started at the age of $15 \mathrm{mo}$; we 
Table 1. Biological input used in the simulation model: default scenario settings

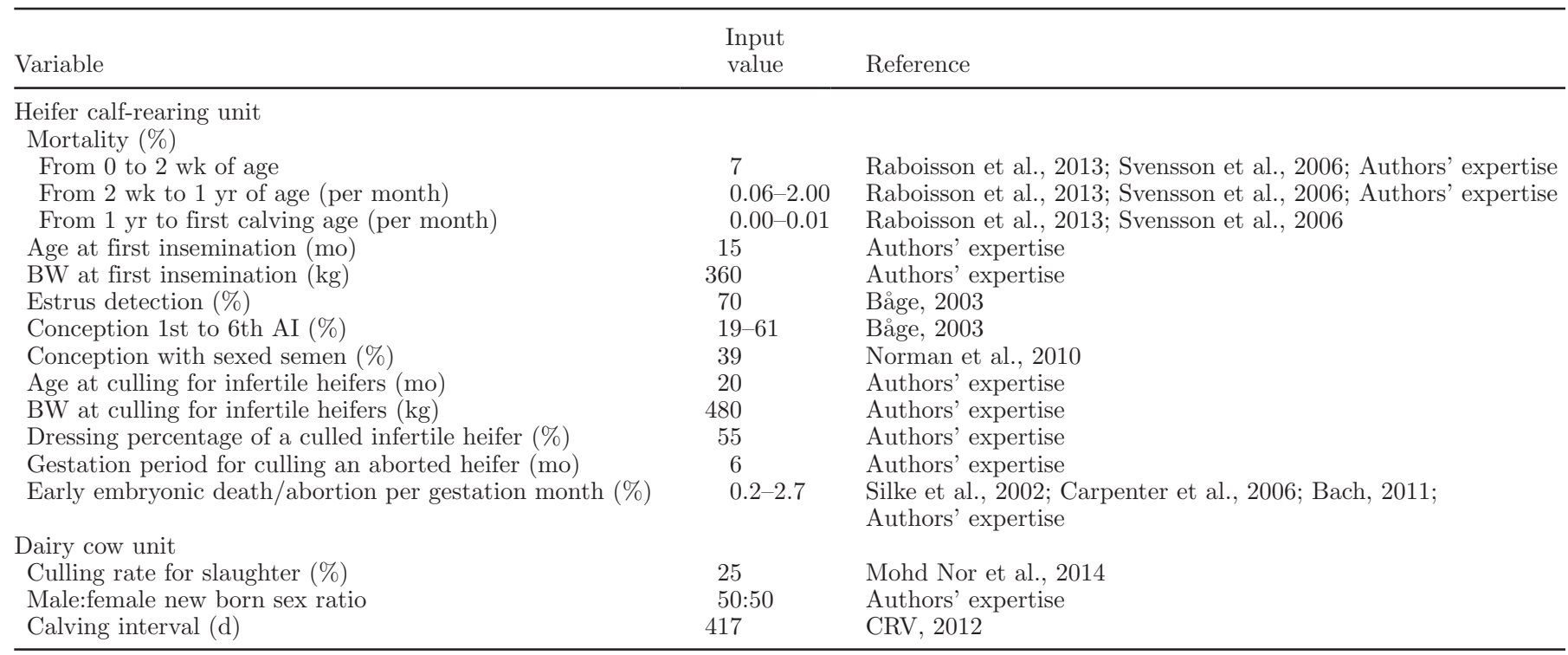

assumed a rearing strategy that resulted in a BW of $360 \mathrm{~kg}$ at that age. The number of heifers that became pregnant was simulated using a binomial distribution, with the number of nonpregnant heifers at an age of at least $15 \mathrm{mo}$ in that stage and the probability of becoming pregnant as inputs (Table 1 ). Conception rates were $60,61,61,46,32$, and $19 \%$ at first, second, third, fourth, fifth, and sixth AI (Båge, 2003). These conception rates ensure that early embryonic death is taken into account. Late embryonic death occurred with rates of 2.7 and $1.5 \%$ per month at second and third gestation months. Abortion, at the fourth and fifth gestation months, occurred at $0.3 \%$ per month and in the remaining months it occurred at $0.2 \%$ per month (Silke et al., 2002; Carpenter et al., 2006; Bach, 2011). An aborted heifer before 20 mo of age was reinseminated unless the gestation month was more than 6 mo. If a heifer failed to get pregnant after the sixth insemination (or after 29 mo) or aborted after 20 mo of age or after gestation of 6 mo, they were defined as being an infertile heifer and subsequently slaughtered. All probability parameters (culling rate, mortality rates, estrus detection rate, conception rates) of the used binomial distributions are mentioned in Table 1.

Economic Input. The economic analysis was restricted to variable costs only, as the intention of our study was to support tactical level planning (e.g., intermediate-term decision making). At each stage, the variable costs and revenues were calculated based upon the simulated number of animals in each state. Subsequently, the total net cost of rearing was calculated by summing up the costs minus the revenues. The variable costs were the costs of rearing heifer calves (including feed, labor, health, and breeding), the cost of carcass disposal for young stock (in case of death), and the cost of empty slots in the dairy herd unit. The revenues were the revenues obtained from selling infertile and excess heifers.

The cost of an empty slot was defined as the net revenues foregone from having 1 less dairy cow in the herd, calculated as the marginal revenues foregone minus the marginal reduced costs. A dairy cow was assumed to have a yearly milk production of 8,335 kg (LEI, 2012b). Savings in feed costs were based on the energy requirements (VEM) of a cow during a month. The VEM unit is used in the Dutch net energy system, and 1 VEM unit contains $1.650 \mathrm{kcal}$ (Van Es, 1978). The energy requirements for maintenance were set equal to 6,000 VEM per day, and for milk production to $450 \mathrm{VEM} / \mathrm{kg}$ of fat- and protein-corrected milk (Klaas et al., 2012). The fat- and protein-corrected milk was calculated by the formula:

$$
\begin{aligned}
& \text { fat- and protein-corrected milk }= \\
& 0.337+(0.116 \times \% \text { fat })+(0.06 \times \% \text { protein }) \\
& \times \text { average milk production }(\mathrm{kg}) .
\end{aligned}
$$

A fat percentage of $4.38 \%$ and a protein percentage of $3.54 \%$ were assumed. The total energy requirement was therefore 513,750 VEM per month. The marginal feed cost savings for an empty slot during a period of 1 mo were subsequently based on the amount of concentrates needed to cover the total energy requirements for an average cow. This was equal to $546.5426 \mathrm{~kg}$ (1 kg of 
standard concentrates equals $940 \mathrm{VEM}$ ) at a price of $€ 23.60$ per $100 \mathrm{~kg}$. The marginal savings for health care and other variable costs were estimated to be $€ 5.31$ per $100 \mathrm{~kg}$ of milk. The marginal revenue foregone per cow per month was calculated as the foregone milk production multiplied by the milk price (€35.60 per $100 \mathrm{~kg}$ ). Average price levels for the year 2012 were used. The total cost of an empty slot was $€ 82$ per month.

The variable costs of rearing a heifer calf were based on Mohd Nor et al. (2012). These costs consisted of feed, health, breeding, and labor costs. When a calf died, it was assumed to be disposed at a cost (Table $2)$. Infertile heifers were assumed to be sold and slaughtered using a slaughter price of $€ 2.25$ per kilogram and a slaughter weight of $480 \mathrm{~kg} /$ heifer. An excess heifer was sold for life (Table 2). The net cost of rearing young stock was calculated as the sum of the variable costs of rearing, the cost of carcass disposal, and the cost of empty slots, minus the revenues from selling infertile and excess heifers.

Optimal Retention Percentage of Heifer Calves. In the Dutch dairy farming system, a heifer calf is either sold at 2 wk of age or kept for raising as replacement stock. Transport of calves less than $2 \mathrm{wk}$ old is prohibited in the Netherlands. The decision to retain or sell calves is therefore made when the calves are 2 wk old. The optimal number of heifer calves to be retained was defined as the number of heifer calves that minimized the total net cost of rearing replacement heifers. This was also expressed as a percentage: the optimal percentage of heifer calves that should be retained to minimize the total net cost of rearing replacement heifers.

\section{Scenarios and Sensitivity Analysis}

Scenarios. The default scenario represents a situation characterized by the input values as shown in Tables 1 and 2. Two additional scenarios were evaluated. (1) The first alternative scenario considered an earlier first-calving age, achieved by reducing the age at first insemination without compromising milk production in the first lactation. For this scenario, an increased growth pattern was assumed so that $360 \mathrm{~kg}$ of BW was reached at 13 mo of age; consequently, the first insemination occurred 2 mo earlier than in the default situation. Due to the reduction in the rearing period, the first-calving age ranged from 22 until 27 mo of age. With the increased growth rate, the costs of rearing were increased. The monthly costs to rear a heifer calf from birth to 3,3 to 6,6 to 14,14 mo to pregnant, and pregnant heifers were $€ 126, € 42, € 46, € 76$, and $€ 59$, respectively (Mohd Nor et al., 2012). (2) The second scenario considered the insemination of heifers with sexed semen. In Dutch herds, sexed semen is commonly used in heifers. For this scenario, it was assumed that

Table 2. Economic input used in the simulation model: default scenario settings

\begin{tabular}{|c|c|c|}
\hline Input variable & $\begin{array}{l}\text { Input } \\
\text { value }\end{array}$ & Reference \\
\hline \multicolumn{3}{|l|}{ Heifer calf-rearing unit } \\
\hline \multicolumn{3}{|l|}{ Costs of rearing ( $€ /$ young stock per month) } \\
\hline 3 mo until 6 mo & 35 & Mohd Nor et al., 2012 \\
\hline $6 \mathrm{mo}$ until $14 \mathrm{mo}$ & 42 & Mohd Nor et al., 2012 \\
\hline 14 mo until pregnant & 69 & Mohd Nor et al., 2012 \\
\hline Less than 1 yr of age & 15 & Rendac, 2013 \\
\hline More than 1 yr of age & 23 & Rendac, 2013 \\
\hline Price of heifer calf at 2 wk of age $(€ /$ animal $)$ & 45 & LEI, 2012a \\
\hline Market value of excess heifer ${ }^{1}(€ /$ animal) & 985 & LEI, 2012a \\
\hline Slaughter value of infertile heifer ${ }^{2}(€ /$ animal $)$ & 594 & LEI, 2012a \\
\hline Additional cost of sexed semen ( $€ /$ dose $)$ & 15.50 & CRV, 2014 \\
\hline \multicolumn{3}{|l|}{ Dairy cow unit } \\
\hline
\end{tabular}

${ }^{1}$ An excess heifer was a replacement heifer for which there was no slot available in the dairy cow unit, and which was sold.

${ }^{2}$ Slaughter value was calculated as the average BW at $20 \mathrm{mo}(480 \mathrm{~kg})$, multiplied by the dressing percentage $(55 \%)$, multiplied by the price of slaughtered meat per kilogram (€2.25).

${ }^{3}$ Cost per empty slot reflected the net revenues foregone of 1 dairy cow less. It was calculated as marginal revenues foregone minus marginal costs. Marginal revenue foregone was calculated from the milk production of an average cow in $2012(8,335 \mathrm{~kg})$ multiplied by the milk price (€35.60 per $100 \mathrm{~kg}$ ). Marginal costs of feeding used the amount of energy (VEM) needed for the maintenance and milk production (corrected for fat and protein production) of a cow. This was then translated into the amount of concentrate $(546.5426 \mathrm{~kg} / \mathrm{mo})$ and multiplied by the price of concentrate $(€ 23.60$ per $100 \mathrm{~kg}$ ). The marginal cost for health care and other costs were also included (€5.31 per $100 \mathrm{~kg}$ of milk). The fat- and protein-corrected milk was calculated using the formula fat- and protein-corrected milk $=0.337+(0.116 \times \%$ fat $)+(0.06 \times \%$ protein $) \times \mathrm{kg}$ of milk. Fat percent was 4.38 and protein percent was 3.54 . 
all heifers were inseminated with sexed semen (until the sixth insemination), and that the chance of having a heifer calf by sexed semen was $91.6 \%$ (Frijters et al., 2009 ) and the conception rate was $39 \%$ (Norman et al., 2010). The additional cost of sexed semen was assumed to be $€ 15.50$ per dose (Table 2).

Sensitivity Analysis. Two sets of sensitivity analyses were performed. The first set explored the effect of individual variables on the net rearing costs. In these analyses the retention percentage of replacement heifers was fixed at the optimal level as determined in the default scenario. For each variable, a value higher and lower than the default value was used. These values reflected a realistic range for the input variable, with values taken from literature and organizations and experts in the Dutch dairy sector. The following biological variables were investigated: calving interval $(+10$ and $-10 \mathrm{~d})$, mortality of young stock per month $(+0.5$ and $-0.5 \%)$, culling rate of dairy cows $(+5$ and $-5 \%)$, conception rate $(+10$ and $-10 \%)$, and estrus-detection rate $(+20$ and $-20 \%)$. In addition, a situation was analyzed where a sudden increase in the disease incidence in the dairy herd unit occurred. This lead to an increase in the culling rate of dairy cows to $35 \%$ once every $10 \mathrm{yr}$ (disease event probability of 0.1 ) and once every $4 \mathrm{yr}$ (disease event probability of 0.25 ). In the default situation, no sudden increase was observed and the probability of the disease event was therefore 0 . The following economic variables were investigated: cost of empty slots (€56 and €126 per slot month), average cost of rearing a heifer $(€ 1,370$ and $€ 1,640)$, meat price for slaughtering ( $€ 1.60$ and $€ 2.35 / \mathrm{kg}$ ), and market value of an excess heifer (€825 and €1,045). The values for the cost of empty slots were created by using a lower (€32/100 kg) and higher (€42/100 kg) milk price. The values for the average cost of rearing a heifer were created by increasing and decreasing the rearing costs by $€ 5$ per month.

The second set of sensitivity analyses explored the effect of different herd characteristics and management factors on the optimal retention percentage of replacement heifers and the associated total net cost of rearing. For each variable, a range of possible values was investigated. The following variables were investigated: calving interval (385 to $445 \mathrm{~d}$ ), average mortality of young stock (0 to 18\%), culling rate of dairy cows (10 to $40 \%$ ), disease event probability (0.0 to 0.5 ), cost of empty slot (€20 to €140), and average costs of rearing (€1,000 to €2,000).

\section{RESULTS}

The optimal retention of 2 -wk-old heifer calves was $73 \%$ in the default scenario (Figure 1). The results (mean, 5th, and 95th percentile results) for the herd characteristics in the default scenario are presented in Table 3 and expressed as a number per herd per year. At the optimal retention percentage, the average size of the herd was 93 dairy cows, and varied between 83 and 99 dairy cows (5th and 95th percentiles). An average of 23 dairy cows were culled per year, with a variation between 16 and 31 dairy cows (5th and 95th percentiles). The average number of heifer calves born was 41 . On average, 3 heifer calves died before they reached 2 wk of age, and 1 heifer calf died between the ages of $2 \mathrm{wk}$ and first calving. In addition, 4 heifers were culled due to infertility and 1 heifer aborted. The average number of young stock present during the rearing period was 54 , and ranged between 44 and 64 (5th and 95th percentiles). On average, 24 heifers successfully reached first calving age and 1 heifer was sold as excess. The average first calving age of the herd was 25 mo.

The economic results (mean, 5th, and 95th percentiles) for the default scenario are presented in Table 4 ; the variables are expressed per herd per year. The average total cost of rearing replacement heifers was $€ 37,854$, and varied from $€ 31,063$ to $€ 44,609$ (5th and 95 th percentiles). The average cost of empty slots in the dairy herd unit was $€ 7,190$, and varied between $€ 983$ and $€ 16,870$ (5th and 95 th percentiles). The average cost of carcass disposal was $€ 55$. The average revenues from selling infertile and excess heifers were $€ 2,318$ and $€ 1,335$. The net cost of rearing was estimated at an average of $€ 40,939$, and varied from $€ 29,261$ to $€ 52,132$ (5th to 95 th percentiles).

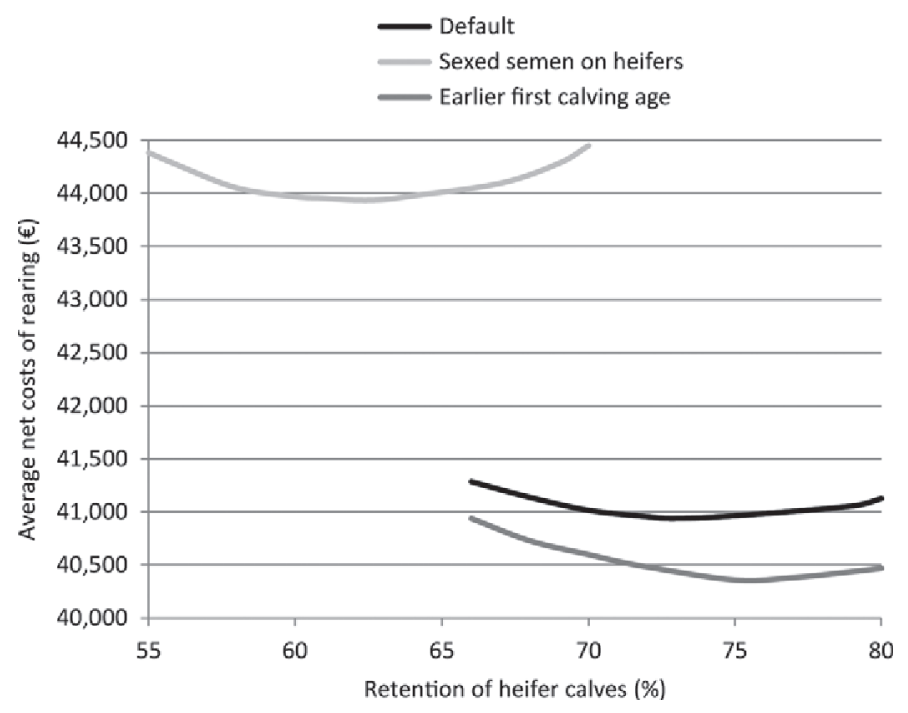

Figure 1. The net cost of rearing for different retention percentages of heifer calves for the 3 scenarios: default, earlier first calving, and sexed semen. 
Table 3. Herd characteristics for the default scenario, expressed per herd per year, with an optimal retention of $73 \%$ of 2 -wk-old heifer calves

\begin{tabular}{|c|c|c|c|}
\hline Variable (no.) & Mean & $\begin{array}{c}5 \text { th } \\
\text { percentile }\end{array}$ & $\begin{array}{c}\text { 95th } \\
\text { percentile }\end{array}$ \\
\hline \multicolumn{4}{|l|}{ Heifer calf-rearing unit } \\
\hline Number of newborn heifer calves & 41 & 30 & 52 \\
\hline Number of dead heifer calves, before 2 wk of age & 3 & 0 & 6 \\
\hline Number of dead heifers, 2 wk to 1 yr of age & 1 & 0 & 2 \\
\hline Number of dead heifers, more than 1 yr of age & 0.03 & 0 & 0.22 \\
\hline Number of infertile heifers & 4 & 1 & 8 \\
\hline Number of aborted heifers & 1 & 0 & 3 \\
\hline Number of first-calving heifers & 24 & 17 & 31 \\
\hline Number of excess first-calving heifers & 1 & 0 & 7 \\
\hline First calving age $(\mathrm{mo})$ & 25 & 25 & 26 \\
\hline Number of young stock present & 54 & 44 & 64 \\
\hline \multicolumn{4}{|l|}{ Dairy cow unit } \\
\hline Number of culled dairy cows & 23 & 16 & 31 \\
\hline Number of empty slot months & 88 & 12 & 206 \\
\hline Herd size & 93 & 83 & 99 \\
\hline
\end{tabular}

In the scenario with an earlier first-calving age, it was optimal to retain $75 \%$ of 2 -wk-old heifer calves. At this optimal retention percentage, the average number of young stock present in the rearing unit was 51 and the average herd size was 94 dairy cows. The average net cost of rearing at the optimal retention percentage was $€ 40,358$ per herd per year (Figure 1). In the scenario using sexed semen on heifers, it was optimal to retain $62 \%$ of 2 -wk-old heifer calves. At this retention percentage, the average number of young stock in the rearing unit was 55 and the average herd size was 91 dairy cows per herd per year. The average net cost of rearing at the optimal percentage was $€ 43,937$ per herd per year (Figure 1).

The results for the first set of sensitivity analyses, where the optimal retention percentage was fixed at the optimal level for the default scenario $(73 \%)$, are presented in Figure 2 (biological variables) and Figure
3 (economic variables). The results showed that herds with a higher culling rate $(5 \%)$, a higher mortality of young stock ( $0.5 \%$ per month), or a disease event probability of $25 \%$ experienced an increase in the average net cost of rearing of $€ 2,986$ to $€ 7,924$ per herd per year, compared with the default scenario. A herd that kept $73 \%$ of the heifer calves and had either a lower conception rate $(-10 \%)$ or lower estrus-detection rate $(-20 \%)$ had, respectively, €1,909 and €3,196 higher average net rearing costs per herd per year compared with the default scenario (Figure 2).

The economic results showed that, in a herd that kept $73 \%$ of 2 -wk-old heifer calves, a higher cost of an empty slot (€126 per slot month due to a higher milk price of $€ 42 / 100 \mathrm{~kg}$ ) resulted in an increase in the average net cost of rearing of $€ 3,972$ per herd per year. The effect of a higher average total cost of rearing ( $€ 1,640$ per heifer) was an increase in the average net cost of

Table 4. Economic results for the default scenario, expressed as $€ /$ herd per year, with an optimal retention of $73 \%$ of 2 -wk-old heifer calves ${ }^{1}$

\begin{tabular}{|c|c|c|c|}
\hline Variable & Average & $\begin{array}{c}5 \text { th } \\
\text { percentile }\end{array}$ & $\begin{array}{c}\text { 95th } \\
\text { percentile }\end{array}$ \\
\hline \multicolumn{4}{|l|}{ Cost $(€ /$ herd per year $)$} \\
\hline Rearing $^{2}$ & 37,854 & 31,063 & 44,609 \\
\hline Empty slot ${ }^{3}$ & 7,190 & 983 & 16,870 \\
\hline Carcass disposal, young stock & 55 & 15 & 105 \\
\hline \multicolumn{4}{|l|}{ Revenues ( $€$ /herd per year) } \\
\hline 2-wk-old heifer calves & 459 & 315 & 585 \\
\hline Infertile heifers & 2,318 & 594 & 4,749 \\
\hline Excess heifers $^{4}$ & 1,335 & 0 & 6,895 \\
\hline Net costs of rearing ( $€ /$ herd per year) & 40,939 & 29,261 & 52,132 \\
\hline
\end{tabular}

${ }^{1}$ The average herd size was 93 dairy cows per year.

${ }^{2}$ The total cost of rearing was the sum of feed cost, labor costs, health costs, and breeding costs.

${ }^{3}$ Cost per empty slot reflected the net revenues foregone of 1 less dairy cow in the herd.

${ }^{4}$ The excess heifers were precalving heifers for which there was no free slot available in the dairy cow unit, and thus needed to be sold. 


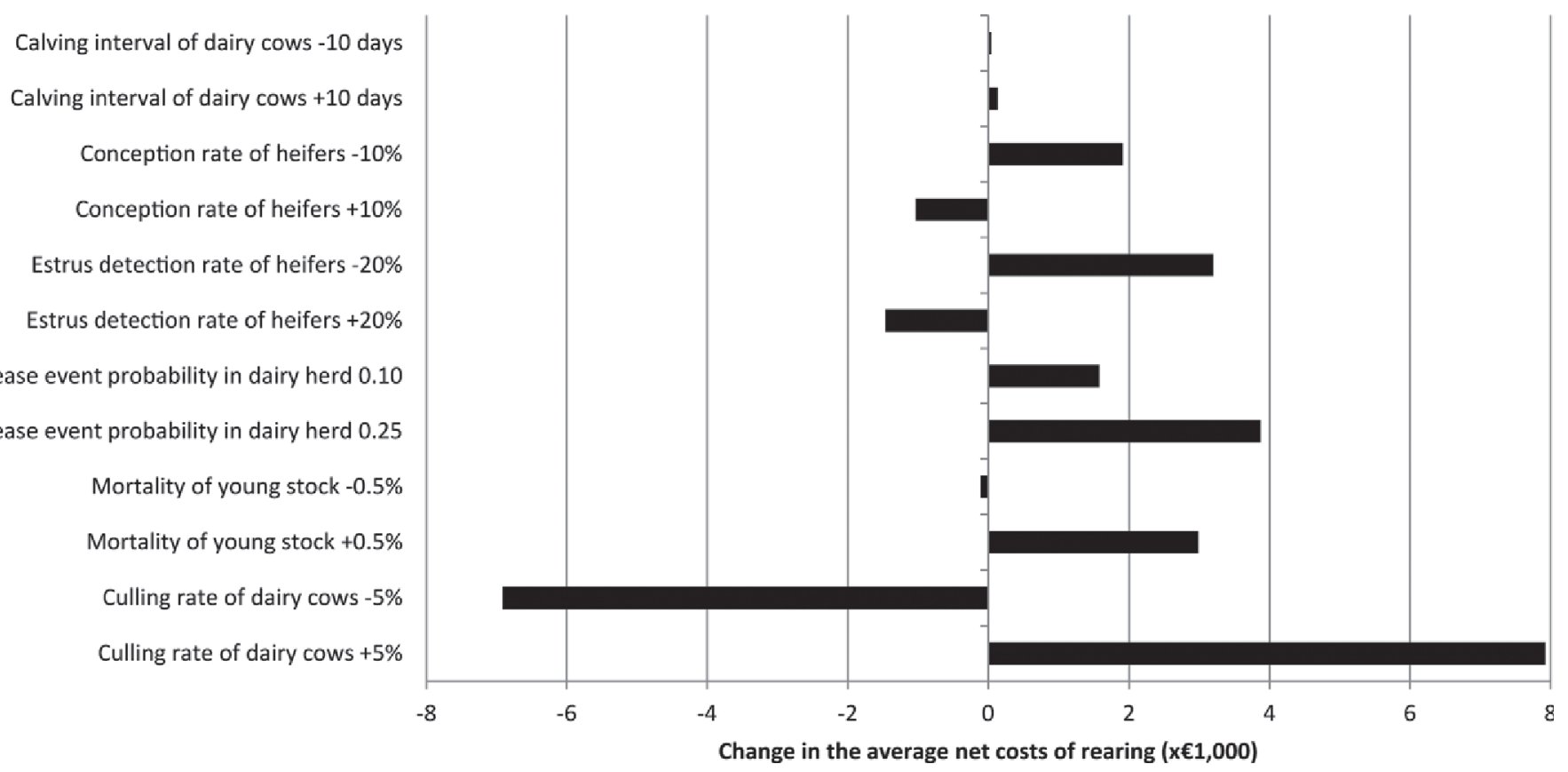

Figure 2. Sensitivity of the net cost of rearing to variation in biological inputs, with the retention percentage of heifer calves fixed at the optimal level for the default situation (73\%).

rearing by $€ 3,470$ per herd per year. A lower market value of an excess heifer ( $€ 825$ per heifer) increased the average net cost of rearing by $€ 294$ per herd per year (Figure 3).
Effects of different herd characteristics and management factors on the optimal retention percentage of 2-wk-old heifer calves are presented in Figure 4. For a herd that had a culling rate of dairy cows of 10, 20, 30,

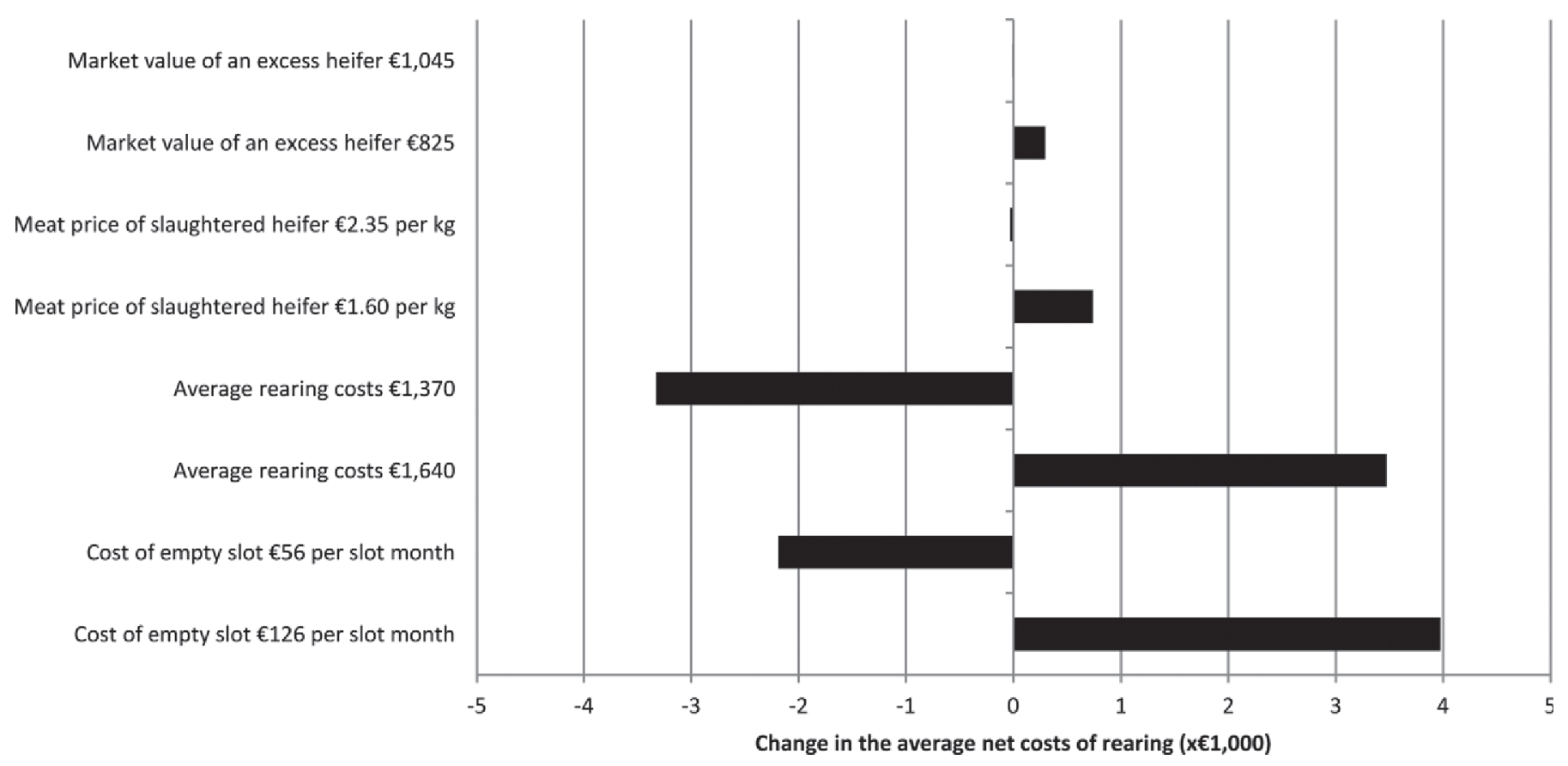

Figure 3. Sensitivity of the net cost of rearing to variation in economic inputs, with the retention percentage of heifer calves fixed at the optimal level for the default situation $(73 \%)$. 
(a)

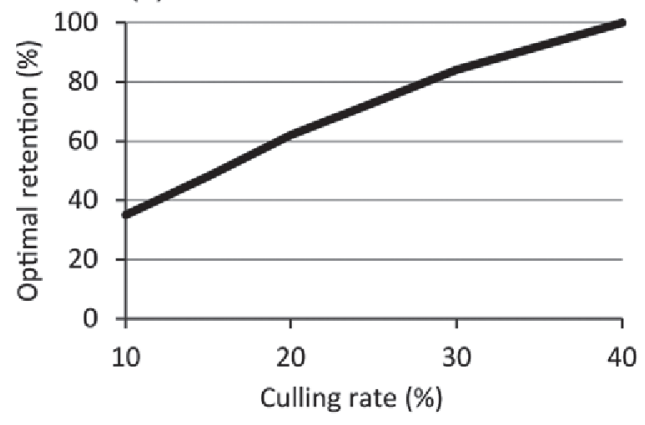

(c)

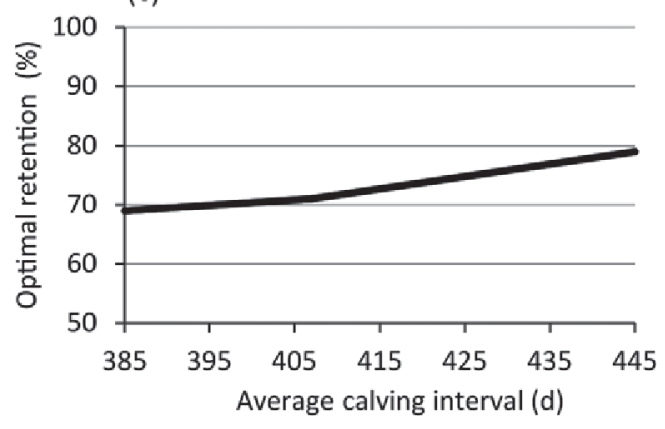

(e)

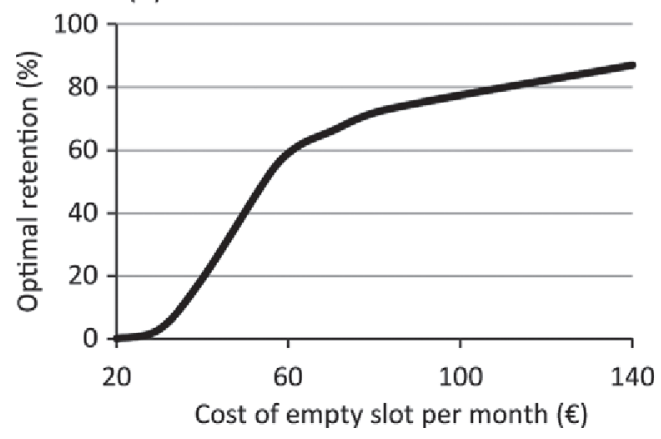

(b)

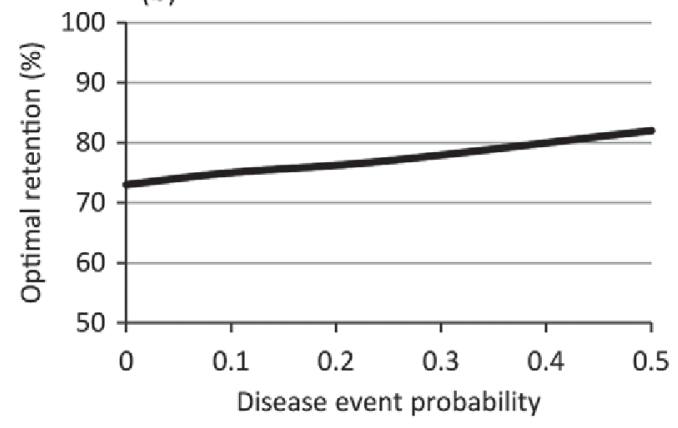

(d)

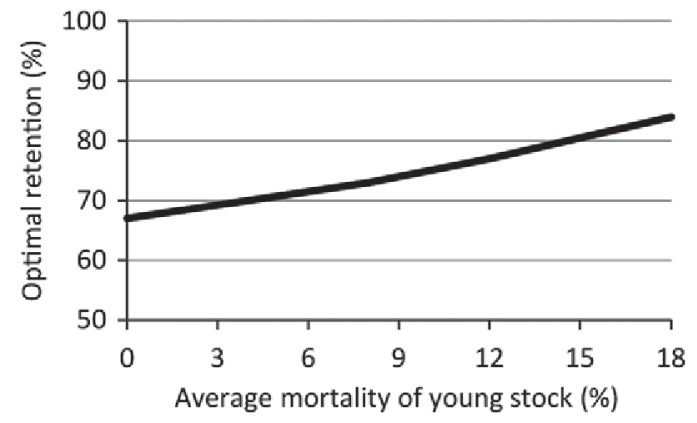

(f)

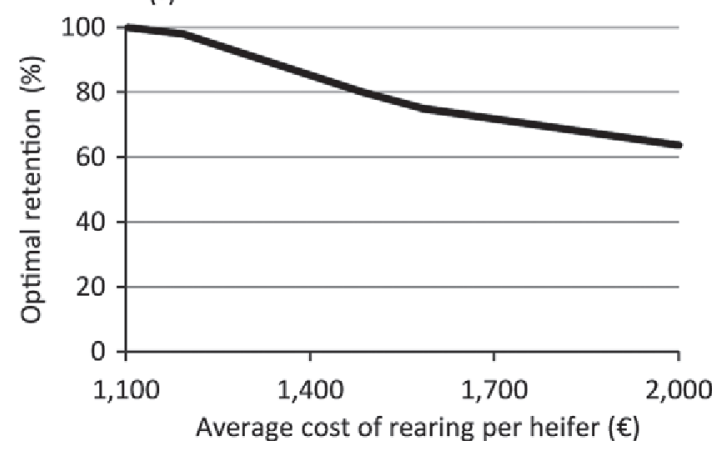

Figure 4. Optimal retention percentage of heifer calves at different (a) culling rates, (b) disease event probabilities, (c) average calving intervals, (d) average mortalities of young stock, (e) cost of empty slots per month, and (f) average costs of rearing per heifer.

or $40 \%$, it was optimal to keep $35,62,84$, or $100 \%$ of heifer calves, respectively (Figure 4). A herd that had a disease event probability of $0.5,0.25$, or 0.1 had an optimal retention of 82,77 , or $75 \%$ of heifer calves per year, respectively. The calving interval also had an effect on the optimal retention percentage. With a lower calving interval (407 d), the optimal retention percentage decreased $(71 \%)$, and with a higher calving interval $(427 \mathrm{~d})$, the optimal retention percentage increased (77\%). A similar effect could be seen for mortality of young stock. No mortality lead to a lower optimal retention of $67 \%$ and a mortality of $12 \%$ lead to an optimal retention of $77 \%$. With a lower ( $€ 50$ per slot per month) or a higher (€120 per slot per month) cost of empty slots, the optimal retention was 49 and $83 \%$.
The rearing costs also had an effect on the optimal retention percentage. Average rearing costs of $€ 1,200$, $€ 1,600$, and $€ 2,000$ lead to an optimal retention of 98 , 75 , and $59 \%$ of heifer calves, respectively.

\section{DISCUSSION}

The model developed in our study included the economic costs and revenues associated with the decision to keep heifer calves for rearing. The model was stochastic, and therefore also able to capture the uncertainty associated with this decision. The model included the uncertainty in mortality of young stock, variation in reproduction of heifers, and in the culling rate of dairy cows. Therefore, the model was able to simulate the 
occurrence of not having enough replacement heifers to timely replace culled dairy cows. As with every simulation model, not all aspects were modeled in a detailed way. For example, the cost of an empty slot and heifer growth rates were based on averages from a previous model (Mohd Nor et al., 2012). The dairy herd enterprise was not modeled in detailed manner and culling of dairy cows was modeled using the involuntary culling rate from a previous Dutch study as an input value (Mohd Nor et al., 2014). In reality, the farmer can delay culling the dairy cow until a replacement heifer is available, and this is not covered in the model. Another limitation of the model was the strict limit on the maximum number of dairy cows (we ran the model with 100 dairy cows). In reality, some flexibility exists in herd size, as overstocking is possible to a certain extent. The discussion on overstocking requires a complex economic calculation in itself; therefore, we restricted the model to exclude overstocking. In our study, the number of slots was a restriction, and milk quota fulfilment was not taken into account. Milk quota will be abolished in the Netherlands in 2015 and the modeled farm represents a near future scenario without milk quota. A further limitation of the model was the assumption of a closed herd (i.e., no replacement heifers were bought), whereas, in reality, herds sometimes buy replacement heifers. We also assumed that enough space was available to raise all heifer calves, and the effect of limited space for heifer calves was not taken into account. In spite of these limitations, the model provided a useful estimate of the total and net costs of rearing replacement heifers. When a herd kept all heifer calves, the average total cost of rearing was $€ 53,880$ per herd per year (data not shown). This was equivalent to an average total cost per heifer per year of $€ 1,584$, which corresponded with a previous Dutch study (Mohd Nor et al., 2012). To calculate the total net cost of heifer rearing, we included the revenues of excess and infertile heifers, as well as revenues forgone due to a (temporary) lack of replacement heifers when dairy cows were culled. Therefore, all costs and revenues associated with the decision to retain heifer calves were taken into account.

Our study showed that it was optimal to keep $73 \%$ of 2-wk-old heifer calves, with an average net cost of rearing of $€ 40,939$ per herd per year. Because there are, to our knowledge, no other studies on the optimal number of heifer calves to be reared as dairy replacements, we were unable to compare our outcome with other studies. Keeping the optimal number of heifers instead of rearing all heifer calves reduced the cost of rearing young stock, but also meant that less replacement heifers were available and, therefore, more empty slots. This meant that the dairy herd unit had a smaller average herd size (93 dairy cows) compared with the situation where all heifer calves were reared (average herd size of 98 dairy cows; data not shown). Dutch herds that rear their own replacement heifers generally keep (almost) all of their newborn heifer calves. A common reason for this practice is to ensure that enough replacement heifers are available to replace culled dairy cows in time. The decision to retain heifer calves for rearing is a decision with high levels of uncertainty. This uncertainty is due to calf mortality, delay in conception during the rearing period, and variation in the culling rate of lactating cows. Rearing all available heifer calves is a management approach which gives more security to farmers, in the sense that is more likely that a replacement heifer is available in time. The results of our study support this and the model showed that situations where a replacement heifer was not available were more frequent when the optimal number of heifer calves was kept. It showed (data not shown) that as fewer heifer calves are retained, the probability of an empty slot increased by 1.9 (retained all) to 2.8 (retained 90\%), 4.8 (retained $80 \%$ ), and $8.7 \%$ (retained $70 \%$ ). However, when (almost) all available heifer calves were reared this approach had a financial disadvantage: the average net cost of rearing was $€ 2,663(6.5 \%)$ higher per year instead of the optimal number. Moreover, feed costs vary greatly from year to year and affect costs of raising heifers. A previous study from the United States estimated, for a herd of 100 cows, that the total cost of rearing heifers was $\$ 32,344$ (€23,928; Tozer and Heinrichs, 2001). Comparing this estimate with the result of our model is difficult, as the parameterization of our model focused on the Dutch dairy farming system. Moreover, our total net cost of rearing also included the consequential losses and returns (empty slots and excess and infertile heifers) associated with the decision to rear heifer calves.

To our knowledge, ours is the first study that has linked the heifer rearing and dairy cow units of a dairy herd to determine the optimal number of heifer calves to be kept in a herd that rears its own young stock. Under default circumstances, we estimated the cost of an empty slot to be $€ 82$ per slot month or $€ 980$ per cow per year. In our model, these costs can be seen as a penalty when the herd size is less than 100 dairy cows. The cost of an empty slot is related to the milk price. With a milk price of $€ 32 / 100 \mathrm{~kg}$, the cost of an empty slot was $€ 56$ per month, causing a reduction in the total net cost of rearing (Figure 3). As was expected, the optimal percentage of calves to be retained for rearing decreased when the cost of an empty slot was lower, as shown in Figure 4e. With low costs of empty slots (below €62 per slot per month; $€ 744$ per cow per year), the reduction in the optimal retention of heifer calves decreased steeply, from 61 to $0 \%$. From this threshold, the annual 
cost of rearing replacement heifers was higher than the cost of an empty slot. Under these circumstances, it is optimal not to rear any replacement heifers, as the investment in rearing does not pay back. Average costs of rearing equal to the sales price of raised heifers (both approximately $€ 1,000)$ resulted in an optimal retention of $100 \%$ (Figure 4f). In the Netherlands, however, the costs for raising heifers are higher than the sales price, and therefore it is not optimal to retain all heifer calves. Dutch farmers raise almost all of their heifers because they underestimate the costs of rearing (Mourits et al., 2000). The underestimation occurs because farmers do not value the costs for feed, housing, and labor. Consequently, farmers who are not aware about the costs of young stock raising retain all heifer calves.

The optimal retention percentage of heifer calves can be influenced by changes in the supply of replacement heifers and changes in the demand from the dairy herd unit. For instance, when the supply of heifer calves was lower due to a higher mortality of young stock, or more dairy cows were needed due to a higher culling rate, the optimal retention percentage of heifer calves increased (Figure 4), as did the total net cost of rearing. With a higher mortality of young stock (18\%), the total net cost of rearing increased by $€ 4,452$. The culling rate of dairy cows had a much higher effect on the net cost of rearing. With a culling rate of $40 \%$, the optimal retention percentage of heifer calves was $100 \%$ and the total net cost of rearing increased by $€ 20,510$. In addition to the normal variation in culling (in our model simulated using a binomial distribution), disease events may occur that lead to a sudden increase in culling. We modeled this as the probability of a disease event, in which case there was a short (1-year) increase in the culling rate. When the probability of a disease event increased to 0.5 , the optimal retention of heifer calves increased to $82 \%$, and the total net cost of rearing was $€ 7,379$ higher.

In the scenario with an earlier first-calving age, the optimal retention of heifer calves was $75 \%$. It was also shown that in this scenario, fewer young stock were present during the rearing period as compared with the default situation. As a result, the total net cost of rearing reduced slightly, by €581 per year (Figure 1). The advantages of a low first-calving age due to a reduction in heifer rearing costs have been documented in other studies (Pirlo et al., 2000; Tozer and Heinrichs, 2001). It was shown that a 1-mo-lower first-calving age (assuming 6\% higher feed costs) in a herd of 100 cows would reduce the total cost of the replacement program by $\$ 1,400$ ( $€ 1,016$; Tozer and Heinrichs, 2001). This is more than our estimate, but our results also confirm the economic benefits of a lower first-calving age.
In our study, sexed semen was assumed to be used only on first-calving heifers. In a previous study, it was demonstrated that the use of sexed semen is more effective when applied to heifers due to a higher conception rate than older dairy cows (especially high-producing cows; Frijters et al., 2009). Therefore, in the Netherlands, sexed semen is predominantly used on heifers. In accordance with our expectations, more heifer calves were produced when sexed semen was used. It was therefore optimal to keep a lower percentage (62\%) of 2 -wk-old heifer calves. However, at the optimal percentage, the costs of rearing are higher $(€ 43,937)$ than in the default situation because of the higher costs for insemination and lower conception rate.

In our model, we assumed that all 2-wk-oold heifer calves are similar, and as they become replacement heifers they were also assumed to have similar milk production as the culled dairy cow. In reality, however, some heifer calves are superior to others, and with genomic selection the best heifer calves can be selected (Thomasen et al., 2014). The genomic test can be applied to every heifer calve born and recently this has been accepted and is widely used in practice by farmers as it is relatively cheap and accurate (Hayes et al., 2013). However, future research is needed to determine the economic value of applying genomic selection at commercial dairy farms. Likewise, beef semen was another method used on lower tier dairy cows to automatically keep only the best heifer calves for the next generation and at the same time to get a higher price for the calves that are sold.

Assuming the average outcomes of the model in the default scenario (optimal retention of $73 \%$ of heifer calves, total net cost of rearing of $€ 40,939$, and a herd size of 93 dairy cows with an average milk production of $8,335 \mathrm{~kg} /$ cow per year), the average net cost of rearing accounted for $12 \%$ of the cost price of milk ( $€ 44.29 / 100$ $\mathrm{kg}$; LEI, 2012c). This means that the rearing of replacement heifers is an important part of the cost of milk production. However, by optimizing the number of heifer calves to be kept for rearing, the average net cost of heifer rearing can be reduced.

\section{CONCLUSIONS}

A simulation model was developed that determined the optimal number of heifer calves to be kept and reared as replacement heifers in a closed dairy herd. For default Dutch circumstances, the optimal retention of 2 -wk-old heifer calves was $73 \%$. By keeping the optimal number of heifer calves, a herd could reduce the total net cost of rearing by $6.5 \%$ as compared with the situation in which all heifer calves were kept and 
reared. Specific herd characteristics (culling rate of dairy cattle, risk of disease events, and young stock mortality) and economic variables (cost of rearing, cost of an empty slot, and price of a replacement heifer) had a large effect on the optimal retention percentage of heifer calves to be reared as dairy replacements.

\section{REFERENCES}

Bach, A. 2011. Associations between several aspects of heifer development and dairy cow survivability to second lactation. J. Dairy Sci. 94:1052-1057.

Båge, R. 2003. Conception rates after AI in Swedish red and white dairy heifers: Relationship with progesterone concentrations at AI. Reprod. Domest. Anim. 38:199-203.

Brickell, J. S., N. Bourne, M. M. McGowan, and D. C. Wathes. 2009. Effect of growth and development during the rearing period on the subsequent fertility of nulliparous Holstein-Friesian heifers. Theriogenology 72:408-416.

Brickell, J. S., and D. C. Wathes. 2011. A descriptive study of the survival of Holstein-Friesian heifers through to third calving on English dairy farms. J. Dairy Sci. 94:1831-1838.

Carpenter, T. E., M. Chriél, M. M. Andersen, L. Wulfson, A. M. Jensen, H. Houe, and M. Greiner. 2006. An epidemiologic study of late-term abortions in dairy cattle in Denmark, July 2000-August 2003. Prev. Vet. Med. 77:215-229.

CRV. 2012. Tabel 2 (in Dutch, vocabulary in English). Accessed Nov. 14, 2013 https://www.crv4all.nl/over-crv/publicaties/ jaarverslagen $/ 327327 /$.

CRV. 2014. Stierenkaarten (in Dutch). Accessed Nov.29, 2014. https://www.crv4all.nl/producten-diensten/genetica/algemeen/ stierenkaarten/437142/.

Frijters, A. C. J., E. Mullaart, R. M. G. Roelof, R. P. van Hoorne, J. F. Moreno, O. Moreno, and J. S. Merton. 2009. What affects fertility of sexed bull semen more, low sperm dosage or the sorting process? Theriogenology 71:64-67.

Gabler, M. T., P. R. Tozer, and A. J. Heinrichs. 2000. Development of a cost analysis spreadsheet for calculating the costs to raise a replacement dairy heifer. J. Dairy Sci. 83:1104-1109.

Hayes, B. J., H. A. Lewin, and M. E. Goddard. 2013. The future of livestock breeding: Genomic selection for efficiency, reduced emissions intensity, and adaptation. Trends Genet. 29:206-214.

Hultgren, J., C. Svensson, D. O. Maizon, and P. A. Oltenacu. 2008. Rearing conditions, morbidity and breeding performance in dairy heifers in southwest Sweden. Prev. Vet. Med. 87:244-260.

Klaas, B., J. van Middelkoop, W. Ouweltjes, G. Remmelink, and H. Wemmenhove, ed. 2012. Handboek Melkveehouderij. Roodbont Publishers B.V., the Netherlands.

Koenen, E. P. C., and A. F. Groen. 1996. Genetic analysis of growth patterns of black and white dairy heifers. J. Dairy Sci. 79:495501.

LEI. 2012a. Animal prices. Accessed Nov. 14, 2013. http://www3.lei.wur. $\mathrm{nl} /$ BIN_ASP/show.exe?aktie=vindtoon\&bj=2010\&ej=2013\&lang uage $=\mathrm{US} \&$ Valuta $=2 \&$ publicatieID $=1 \&$ kiestabel $=8.01 \&$ Database $=$ Prijzen.
LEI. 2012b. Feed price. Accessed Nov. 14, 2013. http://www3.lei. wur.nl/BIN_ASP/show.exe?aktie=vindtoon $\& b j=2010 \& e j=2013 \&$ language $=\mathrm{NL} \&$ Valuta $=2 \&$ publicatieID $=1 \&$ kiestabel $=2.04 \&$ Data base $=$ Prijzen

LEI. 2012c. Milk price. Accessed Nov. 14, 2013. http://www3.lei. wur.nl/BIN_ASP/show.exe?aktie=vindtoon\&bj=2010\&ej=2013\& language $=\mathrm{NL} \&$ Valuta $=2 \&$ publicatieID $=1 \&$ kiestabel $=7.04 \&$ Data base $=$ Prijzen.

Mee, J. F. 2008. Perinatal mortality in heifers - An emerging problem. Cattle Pract. 16:166-173.

Mohd Nor, N. M., W. Steeneveld, and H. Hogeveen. 2014. The average culling rate of Dutch dairy herds over the years 2007 to 2010 and its association with herd reproduction, performance and health. J. Dairy Res. 81:1-8.

Mohd Nor, N., W. Steeneveld, M. C. M. Mourits, and H. Hogeveen. 2012. Estimating the costs of rearing young dairy cattle in the Netherlands using a simulation model that accounts for uncertainty related to diseases. Prev. Vet. Med. 106:214-224.

Mourits, M. C. M., H. J. Van der Fels-Klerx, R. B. M. Huirne, and M. W. C. Huyben. 2000. Dairy-heifer management in the Netherlands. Prev. Vet. Med. 46:197-208.

Norman, H. D., J. L. Hutchison, and R. H. Miller. 2010. Use of sexed semen and its effect on conception rate, calf sex, dystocia, and stillbirth of Holsteins in the United States. J. Dairy Sci. 93:3880 3890.

Pinedo, P. J., A. De Vries, and D. W. Webb. 2010. Dynamics of culling risk with disposal codes reported by Dairy Herd Improvement dairy herds. J. Dairy Sci. 93:2250-2261.

Pirlo, G., F. Miglior, and M. Speroni. 2000. Effect of age at first calving on production traits and on difference between milk yield returns and rearing costs in Italian Holsteins. J. Dairy Sci. 83:603-608.

Raboisson, D., F. Delor, E. Cahuzac, C. Gendre, P. Sans, and G. Allaire. 2013. Perinatal, neonatal, and rearing period mortality of dairy calves and replacement heifers in France. J. Dairy Sci. 96:2913-2924.

Rendac. 2013. Tarievenlijst (in Dutch). Accessed Mar. 2, 2014. http:// www.rendac.nl/nl/footer-quicklinks/rendac-tarieven/.

Silke, V., M. G. Diskin, D. A. Kenny, M. P. Boland, P. Dillon, J. F Mee, and J. M. Sreenan. 2002. Extent, pattern and factors associated with late embryonic loss in dairy cows. Anim. Reprod. Sci. $71: 1-12$.

Svensson, C., A. Linder, and S. O. Olsson. 2006. Mortality in Swedish dairy calves and replacement heifers. J. Dairy Sci. 89:4769-4777.

Thomasen, J. R., C. Egger-Danner, A. Willam, B. Guldbrandtsen, M. S. Lund, and A. C. Sørensen. 2014. Genomic selection strategies in a small dairy cattle population evaluated for genetic gain and profit. J. Dairy Sci. 97:458-470.

Tozer, P. R., and A. J. Heinrichs. 2001. What affects the costs of raising replacement dairy heifers: A multiple-component analysis. J. Dairy Sci. 84:1836-1844.

Van Es, A. J. H. 1978. Feed evaluation for ruminants. I. The system in use from May 1977 onwards in the Netherlands. Livest. Prod. Sci. 5:331-345.

Vonk Noordegraaf, A., J. A. A. M. Buijtels, A. A. Dijkhuizen, P. Franken, J. A. Stegeman, and J. Verhoeff. 1998. An epidemiological and economic simulation model to evaluate the spread and control of infectious bovine rhinotracheitis in the Netherlands. Prev. Vet. Med. 36:219-238. 